\title{
Being Alive, Living a Life. The Unity of the Concept of Life in Pseudo-Dionysius the Areopagite
}

\author{
TOMASZ STĘPIEŃ \\ Cardinal Stefan Wyszyński University in Warsaw \\ t.stepien@uksw.edu.pl, ORCID: 0000-0003-2422-1812
}

\begin{abstract}
The writings of Corpus Dionysiacum present a concept of life which is different from the one that we profess nowadays. Its view is backed up mainly by the Platonic tradition, which since the times of Plato has tended to see life as an intellectual principle. Therefore, in the Neoplatonic system we can find the conviction that life, in its fullest sense, is intellectual and at its peak is a vision of the One. In the system of Proclus, life, apart from being a principle, is also a god and the main principle of the whole world of intellectual and intellective gods. Pseudo-Dionysius in his writings exploits the concept of the unparticipable and participable principle, and since God is for him Trinity completely beyond participation and knowledge, the divine names play the role of participable henads. However, for Dionysius, names are neither hypostases nor living gods, which is clearly visible in case of the name of Life. All things participate in the name of life and in this name God is the only principle of life in the universe. However, life is not a property to own, but rather a constant struggle to approach the Trinity. Therefore, by committing a sin, an angel or a man loses life, which in the case of a man can be regained through sacramental activity. An analysis of the thoughts of Pseudo-Dionysius reveals a conception of life which is unified contrary to its shattered modern understanding. While biological, mental, moral lives fundamentally differ for us, for Dionysius those are merely aspects of the same thing, and therefore in his view life can be lost and regained not only in the metaphorical, but also the ontological sense.
\end{abstract}

Keywords: Pseudo-Dionysius The Areopagite, Plotinus, Life, Christian Neoplatonism, Proclus

Speaking about the Pseudo-Dionysius the Areopagite contemporary scholars often underline that as a Christian writer heavily influenced by Pagan Neoplatonism he treats many of the presented topics in a unique way. The understanding of life is certainly one of them. But what is probably even more interesting, in Pseudo-Dionysius's writings we can clearly see that the concept of life, while being typical of ancient views, is very different from our contemporary approach. The contemporary perception, influenced by the development of sciences, is often fragmented and therefore lacks a comprehensive character.

There is life in biological sense, which first comes to mind when the topic is discussed. Life means the set of physical processes that occur in our bodies, but even when we reject reductionism, which treats mental processes in a material way, we 
rarely think of our intellectual cognition as the most important indication of being alive. Even if we call cognitive processes "mental life," we often separate it from the biological one and we understand them as separate things.

A second fundamental division, which is obvious in the contemporary approach, is the fact of the difference between being animated, being alive in the biological and even mental sense, and leading a daily life. For us one can be only alive or dead, and we have only a vague understanding of having more or less life. We rather tend to add to the life the quality of being good or bad, less or more happy, but it is not like perceiving someone who has a good life as the one who has more life that the other. In other words, we rather tend to treat life in qualitative not quantitative terms. Moreover, having good life is highly dependent on the factors which are in most cases beyond our control, like physical health, fame, etc. We only metaphorically say that someone whose life is of poor quality is rather dead than alive. Leading a life is also not connected to us with loosing or gaining the life, as the effect of our moral choices. It has no gradation of gaining or losing moral perfection. In this sense, daily life is somehow disconnected from biological life and moral life. So, we see the third division between daily and moral life. Although putting a stress on the division of those aspects of life could seem a bit exaggerated, I think that we cannot say that biological, mental, daily and moral life are perceived by us as one subject.

In this article I intend to show that the study of the topic in Corpus Dionysiacum can show that for Pseudo-Dionysius the Areopagite all those types of life understood in the biological, mental and moral sense were connected with each other and rather viewed as the aspects of one and the same thing. I will also argue that for Pseudo-Dionysius making good and bad moral choices means literally being more or less alive, because it is understood as being closer of farther to God, who is the ultimate source of life.

\section{Life as a Principle in Platonic Tradition}

To understand Pseudo-Dionysius's concept it is necessary to have a closer look at the roots of his doctrine. Life played an important role in the Platonic tradition and was treated as an important principle already in Plato's Dialogues. The most important passages can be found in Sophist, where during the discussion on knowledge life is seen as one of the general attributes of being. ${ }^{.}$The problem is that being, which is in the world of forms, must somehow participate in the intellect (vov s) and therefore it cannot be deprived of life $\left(\zeta \omega \eta^{\prime}\right)$. Having life and intelligence means that it must

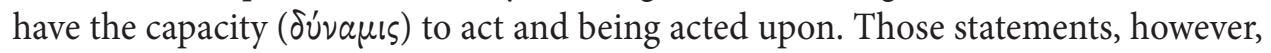

$1 \quad$ Plato, Sophista 248a-259d. 
mean that some change must be introduced to the world of ideas. ${ }^{2}$ But change makes the knowledge of being impossible and therefore there also must be some kind of rest and self-identity, which are the necessary conditions of knowledge. Therefore, the Guest gives Theaetetus the final answer that the world of forms must be both changing and unchanging. ${ }^{3}$

Without further following Plato's reasoning, we can now see that in this fragment he did a very important move by introducing life into the world of the noetic cosmos, which cannot be deprived of it, but rather must be alive in a higher mode. In this sense, life has to be understood as vitality, the principle of being animated. We can also find other elements, which will be important for Neo-platonic followers. Life is seen in the context of some kind of capacity to act, and most of all it is preceded by being, which is connected to it by following the intellect. There is also another aspect which must be noted in confronting life with the contemporary view. Life placed in the world of forms becomes the principle of life for lower beings. Therefore, the ability to live is given as a gift or a share in the principle, which has it in full sense.

We can observe those elements developed in Plotinus's Enneads, but to understand his approach we must realize that in his system life is present almost at all levels of reality, but on each level in a different way. He expresses this idea by saying:

So, the term "life" ( $\zeta \tilde{\eta} \nu)$ is spoken of in many ways, differentiated according to the primary way, the secondary way, and so on in order. The term "living" is said equivocally, that is, it is said in one way of a plant and in another of a non-rational animal, according to the clarity and dimness of the lives they have. ${ }^{4}$

In the second passage of the fourth treatise of First Ennead Plotinus confirms this idea with greater precision:

It has been said many times that the perfect life and the true and real life is in that intellectual nature and that the other sorts of life are imperfect and reflections of life and do not exist perfectly or purely, and are no more lives than the opposite of this. And now let it be said summarily that so long as all living beings are from one source and they do not have life in the same way that it does, it is necessary that the source is the primary life, that is, the most perfect life. ${ }^{5}$

Although here Plotinus seems to speak about the One, it is above any comprehension, and therefore can be called as having the most perfect life only with some

\footnotetext{
Plato, Sophista 248e, 6-249b,1.

Plato, Sophista 249d, 2-4.

Plotinus, Enneades I, 4, 3, 19-24 (Gerson, 74).

Plotinus, Enneades I, 4, 3, 29-40 (Gerson, 74-75).
} 
restrictions, in another passage he adds that it can be called life in "some sense"

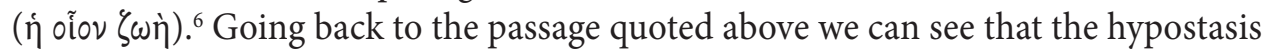
which has life in the full sense is Intellect. But Plotinus not only follows Plato in such statement and in speaking on life as the middle element between being and intellection, he also makes very important additions while developing his view of the

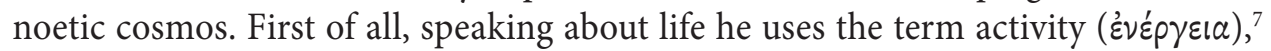
which was invented by Aristotle and fits perfectly to show that being alive means not only being able to perform, but actively performing some kinds of action. Such actions in the noetic world are always eternal and therefore they are understood not as something added to the hypostases but rather as being identical with them. It seems that Plotinus understood life as other supreme genera from Plato's Sophist. Therefore, in this world everything is substance by definition and everything is alive by definition. ${ }^{8}$

The first act of life is the activity of the Good itself which causes eternal production of the whole noetic cosmos. Since, as we have seen above, the Supreme Principle is somehow alive itself, life is called "the activity of the Good, or rather the activity from the Good, an activity which is bounded." By such activity Good/One simultaneously makes Intellect and causes its life. In this state second hypostasis is a Dyad which in its self-establishing vision of the One becomes Intellect, which is the proper principle of life, since it contains within all living things. ${ }^{10}$ Plotinus explains:

Next, there was Motion and Stability in the primary Dyad, there was Intellect and Life in it - that is, perfect Intellect and perfect Life $\left.\left(\zeta_{\omega}\right) \tau \varepsilon \lambda \varepsilon i \alpha\right)$. So, it was not as one Intellect, but as all Intellect, that is Intellect containing all the individual intellects; Intellect as many as these are, and more. And it was alive not as one soul, but as all souls, containing

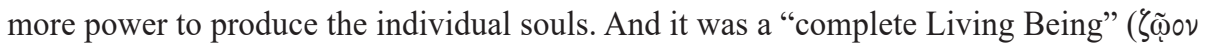
$\pi \alpha \nu \tau \varepsilon \lambda \dot{\varepsilon} \varsigma$ ), containing not only the human being in itself; otherwise, human being would be only in the sensible world. ${ }^{11}$

6 Plotinus, Enneades VI, 8, 7, 52, see also the comment to such way of speaking on the One in: Bussanich, "Plotinus's," 59.

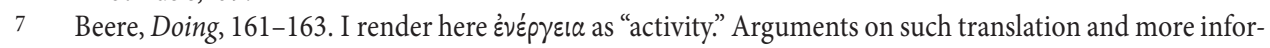
mation about the importance of the term for Neoplatonism and Ancient Christian tradition can be found in: Stępień - Kochańczyk-Bonińska, Unknown, 11-12.

8 Lloyd, Anatomy, 90-91.

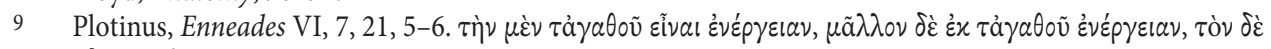

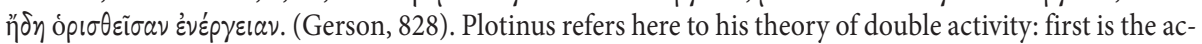
tivity of the substance, and the second activity goes out of the substance. Cf. Bradshaw, Aristotle East and West, 73-96.

10 Plotinus, Enneades VI, 7, 17, 13-16.

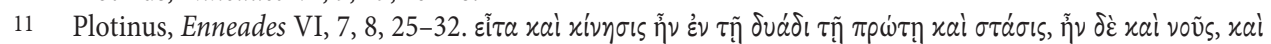

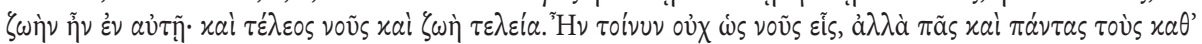

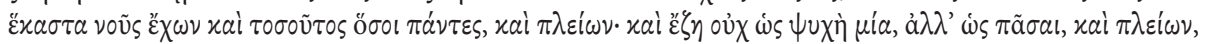


It is important to note that intellect could be the principle of life because it contains in itself all intellects and souls and therefore Plotinus calls it simultaneously

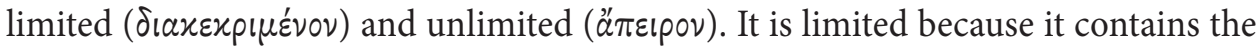
life of each separate intellect and soul, whose life is the life of a concrete living being and therefore limited, and the life of intellect is also unlimited since it is also life as such in a general meaning.

For Intellect is both one and unlimited, and "all together" - and it contains each thing distinguished and yet again not distinguished separately. For how could it be called "unlimited", except because it possesses "all together", that is all life, all soul, and all intellect? Each of them is not set apart by limits. That is why they are one as well. For certainly it must not have one life, but be unlimited, but also one, and one [life] in the sense not that all lives are brought together into one, but because they start from one and remain where they started. Or better, they did not start, but they are in this state always. ${ }^{12}$

Therefore, Intellect as a second hypostasis is simultaneously one and many, one Life and many lives of all intellects and souls. Plotinus also points out that this life is eternal, it did not start at a point in time since the One eternally produces Intellect which is alive as one and as many. It is also important to see that this activity of life is intellectual but occurs differently on subsequent levels. Perfect life of intellect is an intellection, a vision of the One, while the Soul which is submerged in multitude does not have access to pure vision and therefore its activity is rather reasoning.

Finally, we must also point at the view of the whole cosmos in which not only intellectual, but also material part is alive. Plotinus follows Plato's conviction from Timaeus that the world also has a Soul and this soul moves it and makes it alive. This topic will be even more significant in Later Neo-Platonism which directly influenced Pseudo-Dionysius. They would not only claim that the material cosmos is in some sense alive thanks to the Soul, but even that inanimate objects like stones somehow are alive having sort of a soul themselves.

In our short review of the philosophical tradition backing up Pseudo-Dionysius, it is worth to mention Porphyry and especially his Christian student, Marius Victorinus, who introduced the triad of Being, Life and Intellect (esse, vivere, intelligere) into the Trinitarian Theology. The obvious similarity makes it easy to identify esse with

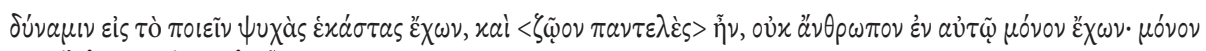

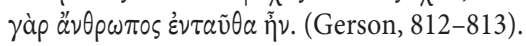

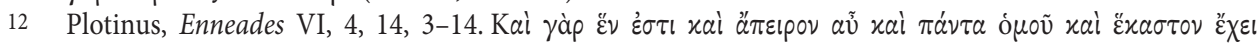

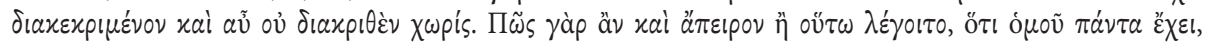

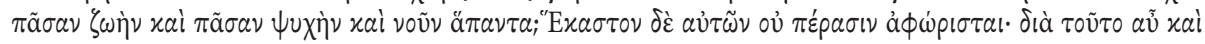

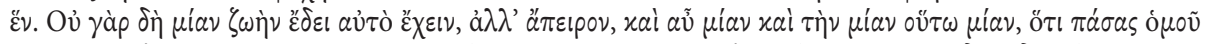

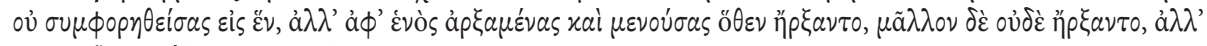

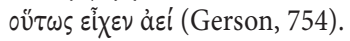


the Father, vivere with the Son, and intelligere with the Holy Spirit. Therefore, arguing on consubstantiality of the Father and the Son, Victorinus presents life (vita) as a second element of the triad which is included in the first one (esse) and comes from it. He finds a relevant passage in the Gospel of John (5:26) "For as the Father has life in himself, even so gave he to the Son also to have life in himself." ${ }^{13}$ Hence the definition of life (likewise the soul) is that it is something which moves itself out of itself (quod a se movetur), we can call by this name both persons of the Trinity, because life is the substance of each one. ${ }^{14}$ And from the Father whose life is preexistence (vitalis preexistentia), the Son is eternally born as existing life (vita existens), and therefore he is a principle of all living things. ${ }^{15}$

What is significant for Marius Victorinus is that it seems obvious that life should be identified with the Son, not only because it is the second element of the intelligible triad. As we have seen in the passage quoted above, Christ calls himself life many times in the Gospel of John. Victorinus refers not only to this passage (5.26) elven times, but he also quotes nine times the verse (14.6) where Christ calls himself road, truth and life and he evokes once the line where the Son says that he is resurrection and life (11.25). Although those fragments would make identification of Christ with the principle of life evident for any Christian writer, Pseudo-Dionysius does not make any use of them. He does not refer even once to those verses in which Christ calls himself by the name of life. As we shall see life is for him the attribute or rather the name of God which should be referred to whole Thearchy, not to any one of Divine Persons.

The last author that must be presented as influential for Pseudo-Dionysius is his pagan teacher - Proclus. One of the most characteristic features of his system is the postulate of placing the henads below the One at the highest levels of reality. Since the One itself cannot be the unity of anything else (it would lose its absolute character then) henads play the role of being participable kinds of unity. ${ }^{16}$ However, those participable kinds of unity are plural only from the perspective of lower things, in themselves they are identical with the One; they make the One participable only from "external" regard, so their status depends on the aspect, in which we take them. The situation is similar from the epistemological perspective. Since henads are the One they cannot be known in themselves, but we can know them thanks to the ef-

13 Marius Victorinus, Adv. Ar. I, 41, 1-10 (SCh 68, 308).

14 Marius Victorinus, Adv. Ar. I, 42, 1-8: "Si igitur Pater 'habet in semet ipso vitam', vita est et substantia eius vita est. Sic et filius; dicit enim: 'ego sum vita'; hoc igitur significat in semet ipso habere vitam: 'ego sum vita'. Pater ergo vita est et filius vita. Omnis vita quod vita est motus est vivificans quibus posse est vivificari; et idcirco definitio animae et vita ista est: quod a se movetur; esse et ut substantia cius istud dicitur. Multo magis ergo esta in deo et $\lambda{ }^{\prime} \gamma \omega$. Quid ergo dicimus? Vita pater et substantia est, et se movens substantia, et nihil est aliud se movens motio nisi vita. Ipsa igitur et substantia et vita." (SCh 68, 312).

15 Marius Victorinus, $A d v$. Ar. I, 51, 15-17. "Vita autem filius, vita motio, a vitali preexistentia, vita existentia in constitutione et aparentia omnium totorum..." (SCh 68, 348). 
fects which they produce. What is important here is that we always know henads from the perspective of plurality which they unite, so we must always be aware of their individual character. They are the One, but they never lose identity as henads and, what is very important in our case, each of them is one of the highest gods. ${ }^{17} \mathrm{In}$ the Theology of Plato Proclus says that "there are three total monads ( $\mu$ ovádes) which are entirely beyond the gods that are divided according to parts, viz. essence, life and intellect." ${ }^{\prime 18} \mathrm{He}$ also explains that since in this triad essence is something intelligible $(\nu \circ \eta \tau \tilde{\omega} \nu)$ and intellect is intellectual ( $\nu$ \&p $\tilde{\omega} \nu)$, life is in between and therefore linking

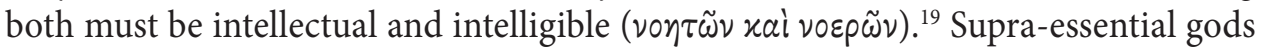
are only the beginning and the top of the whole universe of life principles. In the noetic cosmos we can find a huge number of gods that are the subsequent elements of the noetic reality. There is no need here to go any further into complicated distinctions of Proclus's world. For our purpose it is sufficient to say that the triad of being, life, and intellect serves as the conceptual framework of distinguishing subsequent levels of gods. Therefore, life also is among them first as unparticipated life and then as other participable variations which are the principles of life for all living beings in the universe. ${ }^{20}$

It is worth to note that the Proclus's view of life as henad differs in one point from his predecessors. As Eric R. Dodds points out he was the first who treated life not as a mere element linking being and intellect, but as distinct hypostasis and a god. ${ }^{21}$ Its role as the active force linking intellect with being is not limited to being dúvauı of intellect, but it becomes the living principle or rather the universe of principles of all kinds of living things. As a consequence, the universe of Proclus becomes even more alive. Although such statement could seem strange, we have already seen that the material universe was a living thing for Neoplatonists. For Proclus the material reality has a new meaning, because specific items have the role in theurgical rites, and they are manifestations and containers of the power of gods linked with them according to cosmic sympathy. Therefore, as Anthony C. Lloyd points out, even stones are "showing more life than they apparently do," and the best example is a moonstone which, according to Proclus could respond to phases of the moon. ${ }^{22}$

\footnotetext{
17 Discussion about the identity of henads is presented by Chlup, Proclus, 115-117.

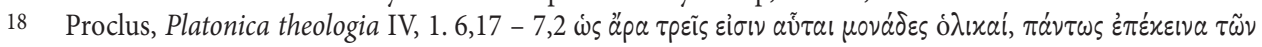

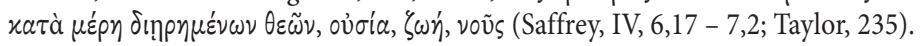

19 Proclus, Platonica theologia IV, 1 (Saffrey, IV, 6, 8-12).

20 For a more precise distinction $c f$. Chlup, Proclus, 122-127. On the specific character of the procession of life $c f$. Lloyd, Anatomy, 113.

21 EricR. Dodds notices that hypostatization of life could be an effect of the influence of the triadic structures found in the Chaldean Oracles as well as Hermetic and Gnostic systems, cf. Dodds, Elements, 253.

22 Lloyd, Anatomy, 124; 133.
} 


\section{Life as a Divine Name}

Pseudo-Dionysius follows Proclus in understanding life as a principle in which all living things participate, but he also makes very significant changes. First, a similar thing which strikes the reader of Dionysius' Divine names is the fact, that God who is the source of life is in himself unparticipable. The Trinity or Thearchy is the source of life above life, and since it is the principle in itself it cannot be participated like the One in the Proclus's system. Therefore, Dionysius constantly reminds us that when he speaks of life he does not describe God in himself. He states it most clearly in the fifth chapter of Divine Names:

I must speak now of those names which tell of the Providence of God. I do not promise to express the absolutely transcendent goodness, being, life, and wisdom of that Godhead beyond all which, as scripture tells us, has its foundation in a secret place above goodness, divinity, being, wisdom, and life. ${ }^{23}$

Since the Trinity is in itself unparticipable, there must be a participable principle of life below, and since it is the unity of all living things, it resembles Proclus's henad. Dionysius calls this principle a name of God which is in between Thearchy and all living things. Life as well as all other such names are called "unified names" ( $\dot{\nu} \omega \mu \varepsilon \dot{v} v \alpha$ ), since they apply not to the persons of the Trinity but rather to the whole godhead. However, there is one more important distinction among those "unified names":

The unified names apply to the entire Godhead, as I showed at length and by way of scriptural examples in my Theological Representations. Hence, titles such as the following-the transcendently good, the transcendently divine, the transcendently existing, the transcendently living, the transcendently wise. These and similar terms concern a denial in the sense of superabundance. Likewise the names which have a causal sense, names like good, beautiful, existent, life-giving, wise, and so forth, are ascribed to the Cause of all good things because of all the good gifts it has dispensed. ${ }^{24}$

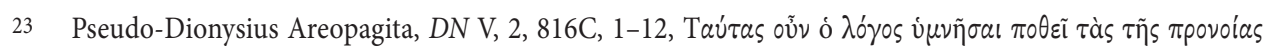

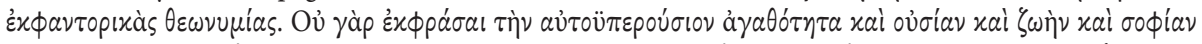

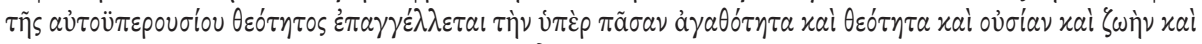

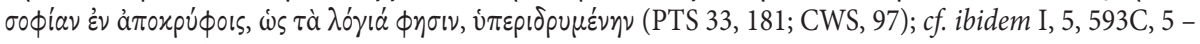
D, 6 (PTS 33, 117).

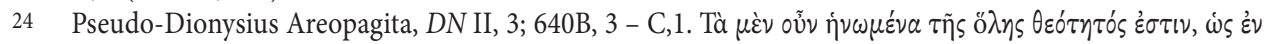

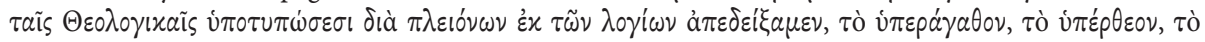

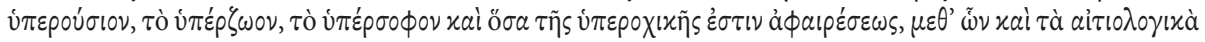

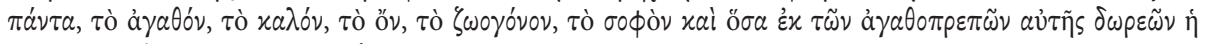

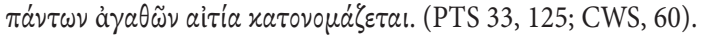


There are two types of unified names: the first one applies to the unparticipable

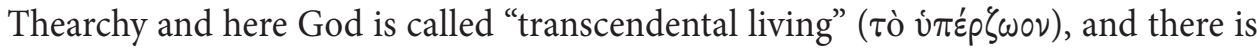
a lower participable version of it, which does not point at the source, but rather at the causation process and here God is called "life giving" ( $\tau$ ò Gwoyóvov). Since God, in the first sense, is absolutely unknowable, we can know him only thanks to how all things come from him, and only the second kind of the unified name can be described and understood in a limited sense. As Dionysius puts it, we "know only those things in which we participate." ${ }^{25}$ Therefore, as we can see, the name of Life in this sense plays the same role as henad of Proclus. However there are important differences.

In all Pagan Neoplatonic systems there was a growing tendency to hypostasize subsequent elements, and life is the best example here. As we remember, according to E.R. Dodds it was Proclus who for the first time understood life not as a force or potency linking intellect with being, but also as a hypostasis. In case of life it makes perfect sense since in this regard life becomes itself a living principle and is also a god, possessing life acquired from the One. For Pseudo-Dionysius life, as well as any other principle is merely an expression of the power of Triune God, and therefore it is not alive in itself and is not a god. Dionysius seems to address this issue in a passage where, as he says, he answers the question of Timothy, who asks how to understand the difference between calling God "life itself" (avं $\left.{ }^{\prime} \zeta \omega \eta^{\prime} \nu\right)$ and "hypostasis of life itself” ( $\tau \tilde{\eta} \varsigma \alpha \dot{v} \tau 0 \zeta \omega \tilde{\eta} \varsigma$ vं $\pi \circ \sigma \tau \dot{\tau} \tau \eta \nu)$. Dionysius explains:

To repeat something frequently asserted already, to call God "life itself" and "power itself" and then "subsistence of life itself," "subsistence of peace itself", "subsistence of power itself," involves no contradiction. The former names are derived from beings, especially the primary beings, and they are given to God because he is the cause of all beings. ${ }^{26}$

In my opinion, Dionysius in this fragment refers to two modes of unifying names which we have mentioned above. Only God can be called hypostasis in the sense that he is the ultimate principle having life in itself - $\tau \tilde{\eta} \varsigma \alpha \dot{v} \tau 0 \zeta \omega \tilde{\eta} \varsigma \dot{v} \pi 0 \sigma \tau \alpha \dot{\tau} \eta \eta \nu$ - and this is what earlier was called unified names in a transcendental and unknowable sense. ${ }^{27}$

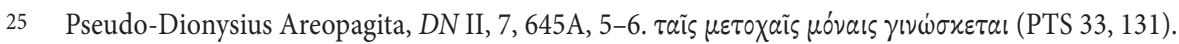

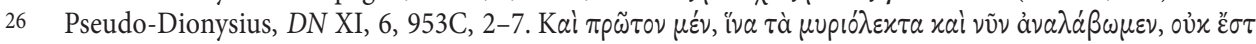

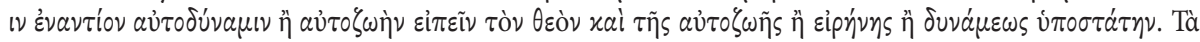

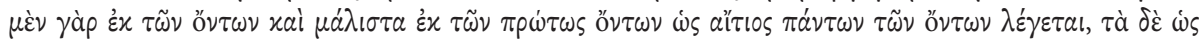

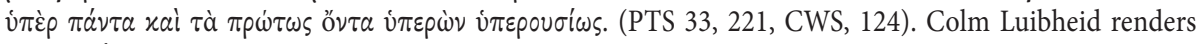

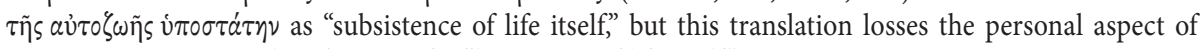
Dionysius expression, therefore I prefer "hypostasis of life itself."

27 Among the scholars there is a long going discussion on whether Pseudo-Dionysius allows the lower levels of beings to be creative principles. Endre von Ivànka, Rene Roque and Eugenio Corsini argue that Dionysius rejects the Neoplatonic notion of lower principles as being creative and causality is reserved only to the Trinity. Ronald F. Hathaway (cf. Hierarchy, XV-XVII) argues that Pseudo-Dionysius fully accepted Proclus's view of lower principles. It is not a proper place to go into the detailed argument, but it must be 
But when unifying name of life is described in causal sense, the Trinity is called life in itself ( $\alpha \dot{\tau} \tau \sigma^{\zeta}\left(\omega \eta^{\prime} \nu\right)$, because this is a description of the same life in the participable aspect. Pseudo-Dionysius underlines that in this second aspect Life cannot be called god or hypostasis:

The absolute being underlying individual manifestations of being as their cause is not a divine or an angelic being, for only transcendent being itself can be the source the being, and the cause of the being of beings. Nor have we to do with some other life-producing divinity distinct from that supra-divine life which is the originating Cause of all Living beings and of life itself. Nor, in summary, is God to be thought of as identical with those originating and creative beings and substances which men stupidly describe as certain gods or creators of the world. Such men, and their fathers before them, had no genuine or proper knowledge of beings of this kind. Indeed there are no such beings. ${ }^{28}$

It is very significant that explaining the status of the divine names and that they are not gods in the Pagan sense, Dionysius speaks mainly about life. If life in its full sense is intellectual, names are only manifestations of the one God not having life in this full intellectual sense, in this regard they are lifeless principles. As a consequence, intellectual life is no longer transferred by lower living beings in the sense present in Proclus. The name of Life is not alive and causing life it cannot give something it itself owns. Therefore, it is rather a channel connecting all things with the source and allowing for participation of the life of the Trinity which is in itself unparticipable. Life is then divine but it is not a divinity. As we remember for Proclus even stones were in some sense alive, because they were infused with divine power of a complementary deity. Therefore, life was something which they had as being divine. Now there is only one God who possesses life and all other beings can participate in him. We see, than, that the mode of participation has fundamentally changed. Lower beings do not "partake" of the higher divine life to have it as their own, but rather they constantly draw it from their source. Because of that, life becomes even

noted that I disagree with the arguments of R.F. Hathaway. Although he certainly found inconsistency in the arguments of Corsini, in my opinion he failed to demonstrate his view. The matter seems to be more complicated, and as I will argue below, the answer may lie in distinguishing different types of causation (like in case of angels who cause understanding not being of lower ranks). I think that it is safe to understand this key passage from Divine Names XI, 6 as a critique of the Neoplatonic view of causality of lower beings, since it is seen this way by other scholars. Cf. Ysabel de Andia (Henosis, 97), who also sees in this passage the critique of the mediative role of gods divided according to the triad: being, life, intellect.

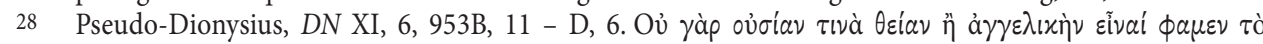

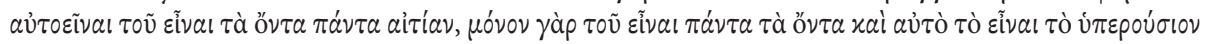

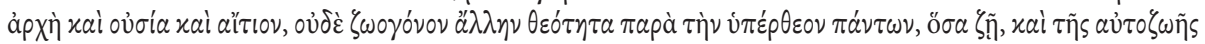

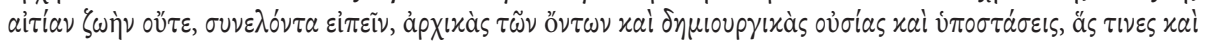

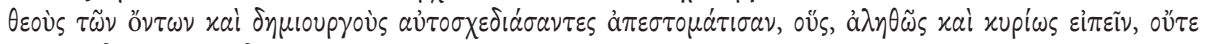

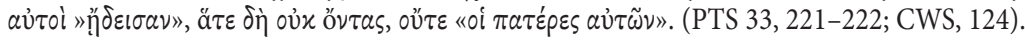


more dynamic and cannot be seen as a static property. Every living being is constantly connected with the name of life. Finally, Dionysius makes another very significant change. In the catalogue of names there is no longer a place for the Neoplatonic triad in its original shape as being, life and intellect. Since intellect cannot be perceived as not performing the act of intellection and thus not being alive, Dionysius replaces it with wisdom..$^{29}$

\section{Participation of All Things in the Name of Life}

One of the consequences of the change in the mode of participation which Dionysius made is the unification of his world. Now the only principle is Triune God and no other being is the life-giver in the sense that it shares its own life. There is only one creator of life. We can observe it in the sixth chapter of Divine Names where Pseudo-Dionysius describes how life is granted to all living things. Life is given to all beings that can participate in it, but this mode of participation depends on the grade of perfection of a given entity and therefore the grade of life. The first and the most perfect creatures which have their fullest share in the gift of life are angels, who "have

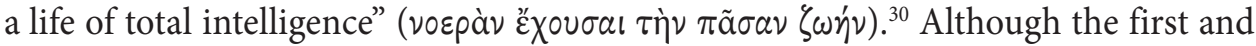
the most perfect beings which participate in life are angels, Dionysius once again underlines that even though their life is perfect and immortal it belongs to them only in a certain measure:

That is why they are described as ever-living and immortal. Though, again, they are not immortal, since they do not have immortality and eternal life by themselves. This is something they have from the creative Cause which produces and preserves all life. ${ }^{31}$

29 I deliberately omit here the longer discussion on the triad of being, life and intellect and the way it changed in the Neoplatonic tradition in relation to Dionysian corpus since in my opinion the issue is less important for understanding the concept of life (for more on the topic $c f$. Dillon - Klitenic Wear, Dionysius, 24-27; Schäfer, Philosophy, 84-88). But I think that replacing Intellect with Wisdom can be seen as something more than putting a biblical equivalent in the place of the Neoplatonic principle, as John Dillon and Sarah Klitenic Wear suggested (Dionysius, 47), but also as a changing the hypostatic principle to an ahypostatic one.

30 Pseudo-Dionysius, DN IV, 2, 180A, 9. (PTS 36, 21). Ysabel de Andia (Henosis, 172; 234-235) speaks about two models of imitation of intellectual life: first is the imitation of the unity of the Persons of Trinity, second is imitation of the angelic life.

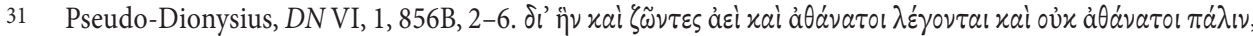

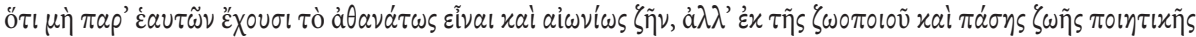
xai бuvoxเxñs aiтías. (PTS 33, 190-191; CWS, 103). 
Despite of their perfection, angels have life only thanks to the one principle of life which is the divine name. ${ }^{32}$ It grants life to all angels, even those who are evil and therefore even demons can have intellectual life thanks to it. ${ }^{33}$ But we also can find in Pseudo-Dionysius the ideas similar to his Neoplatonic predecessors. Angels are also creatures who can pass life to lower beings:

Directly and without arrogance they [angels] have been first to receive this light, and as intermediaries, they have generously passed it on so far as possible to those next to them. They have a generative power, a life-giving power, a power to give increase and completion, for they rain understanding down and they summon the breast which receives them to give birth to a living tide. ${ }^{34}$

Angels also seem to have the powers of generation, life giving, growth and perfec-

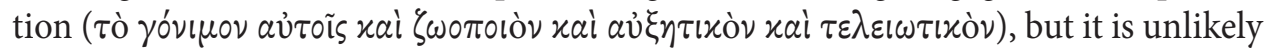
that Dionysius speaks here about giving life as such. He rather describes angels as the authors of intellectual understanding. In this passage he explains the proper meaning of angels symbolized by clouds. And therefore he speaks that as clouds they "rain

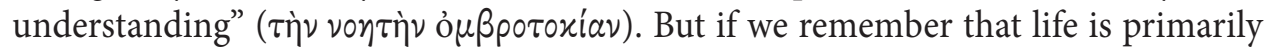
intellectual, providing the ability to understand or make somebody understand is in perfect accord with giving life understood as intellectual activity. Such interpretation seems plausible because when Pseudo-Dionysius speaks about giving life to human souls he does not say that it is done trhough the mediation of angels. ${ }^{35}$ Nevertheless, even in case of giving the lower intelligences understanding, angels do not produce this intellectual vision, but rather transfer it, as clouds transfer water.

Going back to the sixth chapter of Divine Names we can once again see that human souls receive life and can participate in God thanks to the name of Life, and this life is of intellectual nature. Although humans are mortal, and they have life similar to intellectual angelic life, they will be able to have full share in it in the afterlife. ${ }^{36}$

32 Pseudo-Dionysius, CH IV, 1, 177C, 9 - D, 5 (PTS 36, 20); Pseudo-Dionysius, DN I, 3, 589B, 2 - C, 3 (PTS $33,111-112)$.

33 Pseudo-Dionysius, DN VI, 2, 856C, 5-7 (PTS 33, 191).

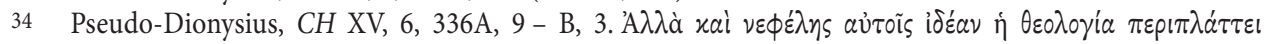

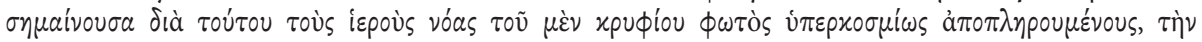

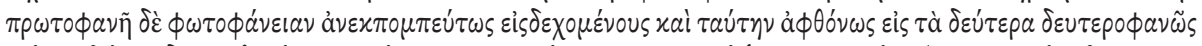

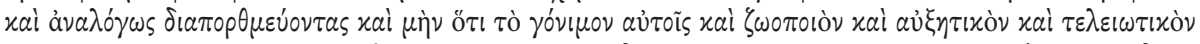

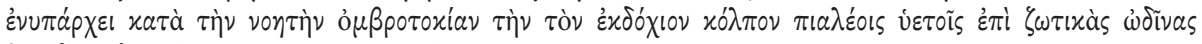

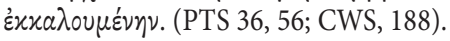

35 Probably the most appealing passage is to be found in: Pseudo-Dionysius, DN IV, 2, 696C, 2-5 (PTS 33, 145).

36 Pseudo-Dionysius, DN VI, 2, 856C, 8 - 857A, 9 (PTS 33, 191-192). After the passage on resurrection Dionysius adds that those things could seem to be "against nature" ( $\pi$ apà $\phi \dot{\sigma} \sigma \nu)$ according to ancients, but for Christians they are rather (vं $\dot{\varepsilon} \rho \phi \dot{\sigma} \sigma v)$. He also mentions the false convictions of "mad Simon," probably referring to the Acts 8:8-24, who was trying to buy the power of giving Holy Spirit from the Apostles. But 
Finally Pseudo-Dionysius speaks of the life of plants and animals and in this passage he once again presents a hierarchy of life from the most to the least perfect:

And whether you talk of the life of intelligence, of reason, of perception, of nourishment, of growth or whatever, if you talk of life, or the source of life or the essence of life, it lives and grants life out of that Life surpassing all life, and it preexists in it as the single Cause of life. ${ }^{37}$

Even in the case of the most perfect life there is a distinction in speaking about

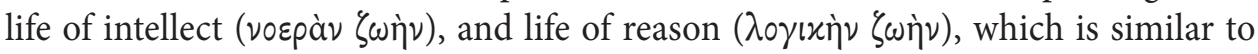
the earlier Neoplatonic approach of treating intellectual vision as a higher activity than reasoning. If then life is an activity, it is primarily an intellectual one, and bodily movement, growth and nutrition are only imperfect echoes of its higher kind.

\section{Losing and Gaining the Life}

In the world of living beings, life in a certain aspect is not received once and for all. Dionysius speaks many times of moving up and down. The share in the name of life is not only given to creatures, but also can somehow be lost and regained. And even if life is not weakened in any way, every being is naturally called to uplift itself to fuller participation in life, which really is the participation in the aspect of the power of God. However, each intellectual creature, even angels can lose the gift of life in a certain aspect. The most obvious example are the demons who turned away from God, that is from the only source of life. They are not evil by nature, but rather they turned evil, and therefore they can also have a share in the intellectual

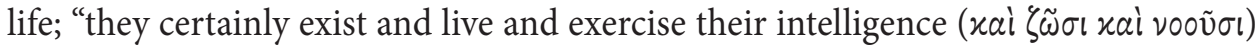
and have within them some stirrings of desire." But this natural activity of intellect is weakened, therefore they somehow have fallen apart from their intellectual

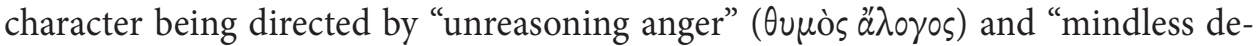

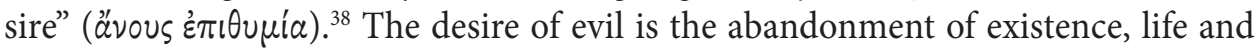

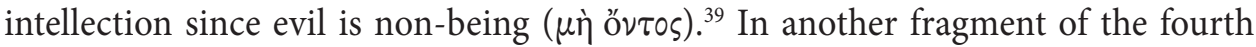
chapter of Divine Names Dionysius says directly that evil is not only the lack of being

here it is not clear why Pseudo-Dionysius refers to him since he only criticizes his usage of arguments based on visible things.

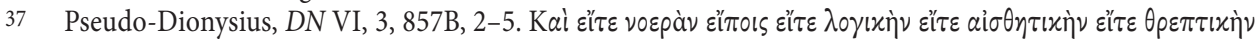

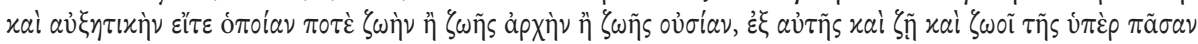

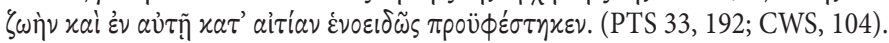

38 Pseudo-Dionysius, DN IV, 23, 725B, 1-10 (PTS 33, 171).

39 Pseudo-Dionysius, DN IV, 23, 725C, 11-12 (PTS 33, 172). 


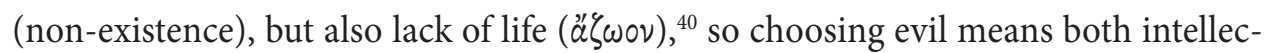
tual impediment and loss of life.

It is worth mentioning that good angels in the hierarchy can also improve their intellectual vision since the lowest choirs of every triad are the rank of purification, and in case of angels purification means getting rid of ignorance. However, explaining this Dionysius does not mention life as intellectual activity ${ }^{41}$ But if we turn to the relation between angels and human souls we return to the concept of intellectual life. Since, as we have seen, angels can grant intellectual vision, this means that they can make human soul "more alive" giving it a more perfect version of its proper activity. An angelic kind of life is the perfect model and the goal which is possible to achieve by human soul. God by the mediation of his names (in this case especially the name

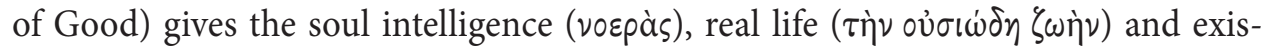
tence ( $\tau$ ò हĩval) and thanks to it: "they can strive towards angelic life." ${ }^{2}$ This uplifting to the state of angelic life means for the soul the higher share in intellectual illumination and higher knowledge, which is granted by God in his names. I think that in those fragments we can observe Dionysian conviction that when human intellect is illuminated by angels it performs better its most perfect activity, and the soul's life is also uplifted to a higher level.

In the world of Dionysius not only angels, but also the whole angelic hierarchy is the model of the ecclesiastical hierarchy of how to get closer to the Trinity. ${ }^{43}$ Especially in case of human beings it is clearly visible that life can be partially lost when one commits a sin. ${ }^{44}$ All of sacramental activity is aimed at gaining an intellectual vision which can be veiled and shadowed by bodily desires. Probably the most striking example of understanding life this way can be found in the passages where the sacrament of baptism is explained (or meditated) in a manner which seems rather philosophical than theological. It seems that for Pseudo-Dionysius the best way to show the meaning of baptism is with the categories of unity and plurality. In baptism the catechumen gains new life which is pointed towards the One:

40 Pseudo-Dionysius, DN IV, 32, 732C, 8 - D, 8. (PTS 33, 177).

41 Pseudo-Dionysius, EH VI, 3, 6, 537A, 3 - C, 8 (PTS 36, 119-120).

42 Pseudo-Dionysius, DN IV, 2, 696C, 2-10 (PTS 33, 145).

43 It is worth to mention that this goal of the Ecclesiastical Hierarchy will be realized in afterlife where the human hierarchy will be incorporated into the angelic one, $c f$. Louth, "The Reception," 136.

44 Hathaway (Hierarchy, XXIV) notices that characteristic way in which Pseudo-Dionysius refers to the Holy Scripture allows him to avoid the problem of sin, which is seen only in the Platonic fashion. Although I disagree that Dionysius avoids the idea of sin, it seems to be true that in the understanding of it he seems to be a straight follower of the interpretations of the Phaedrus myth. It is true especially in seeing the primal effect of sacramental activity as regaining the unity with or focusing life on the One. 
One cannot participate in contradictory realities at one and the same time, and whoever enters into communion with the One cannot proceed to live a divided life, especially if he hopes for a real participation in the One. ${ }^{45}$

The state of having a higher life, which is a gift of God, is not only described as a path towards unity, but is also the life of true and more perfect intellectual knowledge. The light which is so often evoked here is not sensual, but intellectual. Thanks to baptism, the catechumen avoids the darkness of ignorance, ${ }^{46}$ and thanks to the sacrament "the light shines through all his life." In this place, it is worth noticing that for Pseudo-Dionysius even the spoken words play a role similar to the sacrament. They have the power to nourish the soul and give life to it, and this role is best seen in the case of the words of God in the Holy Scripture, which are symbolically depicted

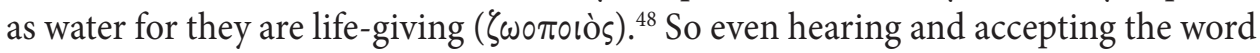
into the intellect gives soul nutrition and sustains its life.

Such a mode of expressing the meaning of baptism, as gaining more unity and life, continues in the case of other sacraments, especially the Eucharist, which is

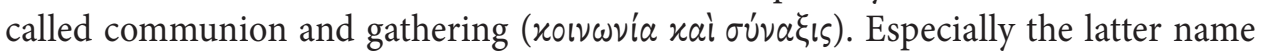
expresses in full the sense of what is the meaning of all sacramental activity focused in the Eucharist:

For a start, let us reverently behold what is above all characteristic of this, though also of the other hierarchic sacraments, namely, that which is especially referred to as "Communion" and "Gathering". Every sacredly initiating operation draws our fragmented lives together into a one-like divinization. It forges a divine unity out of the divisions within us. It grants us communion and union with the One. ${ }^{49}$

Sacramental rites, then, make one from what is fragmented and divided, because the goal is unification with the One. Since fragmentation is characteristic for the material reality, sacraments play the role of lifting the soul from the divided state of the matter and sensual perception to the perfect and unified sphere of intellect. When we consider the Eucharist, it is worth mentioning that the very concept of the

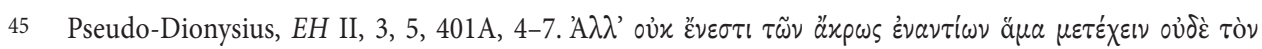

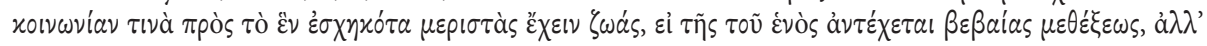

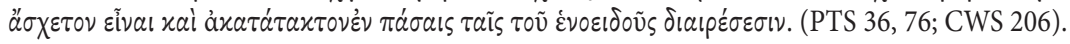

46 Pseudo-Dionysius, EH II, 3, 4, 400B, 8 - C, 8 (PTS 36, 75).

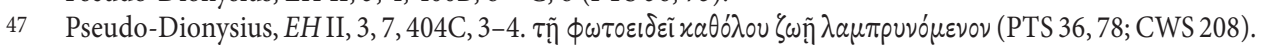

48 Pseudo-Dionysius, Ep. IX, 4, 1109C, 10 (PTS 36, 202).

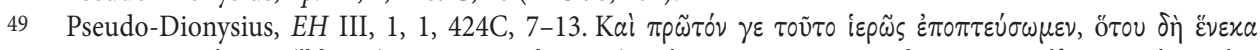

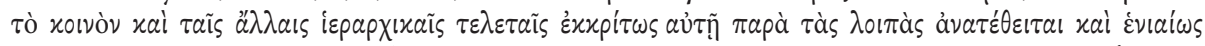

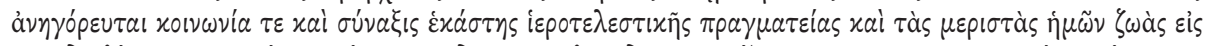

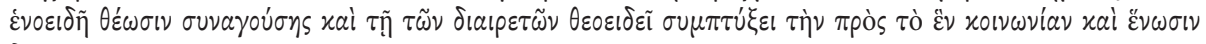

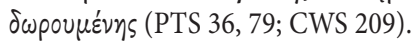


sacrament shifts the topic of striving towards understanding and unity to the level of daily life. The life-giving gathering into One does not occur as a single event, but it is daily practice. Members of Ecclesiastical Hierarchy live the sacramental life in which they obtain intellectual and moral perception. Then moral and sacramental life is only an aspect of participation in the same life which is the Divine Name. The path to unification leads from sensual to intellectual and even beyond intellectual because the utmost unification is above intellect. Therefore, the goal of every human being is simultaneously to have full participation in the divine names (including the name "Life"), and to be unified with the Trinity which is the source of everything. Such program of perfecting life and being uplifted to unification can be observed in the case of monks, who are called the name:

[...] because of the purity of their duty and service to God and because their lives, far from being scattered, are monopolized by their unifying and sacred recollection which excludes all distraction and enables them to achieve a singular mode of life conforming to God and open to the perfection of God's love..$^{50}$

The goal of perfect life is, then, to practice unification of every aspect of life to obtain a single intellectual vision, indispensable to gain the knowledge beyond knowledge in "henosis" with the One. The perfection of life described as unification allows to observe that for Pseudo-Dionysius there is only one life, and the perfection of unified life practiced by the monks is only an aspect of participation in the Divine Name of Life, the same name which offers a natural ability of having intellectual, sensual or vegetative life.

Finally, we must notice the last characteristic feature of this universe. Not only humans and angels are involved in the movement down and up. Every being responses to the call to return to its source and each does it and desires it according to its own ability.

All things are returned to it as their own goal. All things desire it: Everything with mind and reason seeks to know it, everything sentient yearns to perceive it, everything lacking perception has a living and instinctive longing for it, and everything lifeless and merely existent turns, in its own fashion, for a share of it. ${ }^{51}$

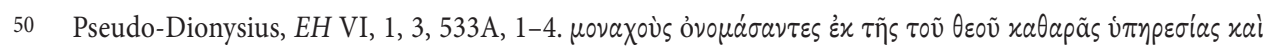

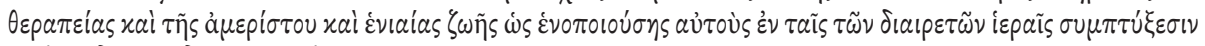

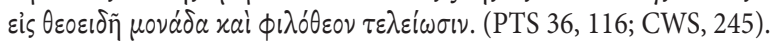

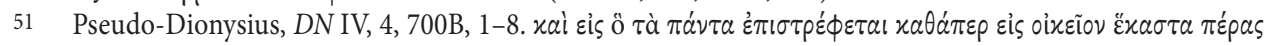

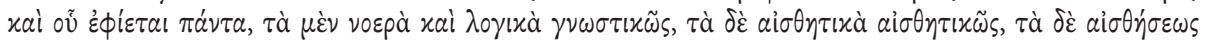

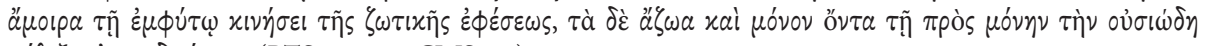

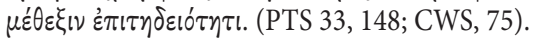


So, even inanimate beings have desire to go up to their source, and Dionysius understands his universe in a similar way as his Pagan teachers, i.e. every being could be called alive in some aspect. The cosmos moves, and this movement is a kind of life which is desired by each existing thing. Discussing the divine name of Peace Pseudo-Dionysius describes the perfect order of the Universe which is what the name means. In this order the movement appropriate to each element is the life which is protected and saved from destruction thanks to the Divine Name of Good. ${ }^{52}$

\section{Conclusion}

To conclude, we must make a general remark. What we have said above has shown that being alive is not only a kind of property which is possessed by a being. Life is not a static but rather a dynamic characteristic of it, and therefore, as Hathaway notices: "Life is not only a property of living things, but that which they strive actively to have. Their being alive is that movement." ${ }^{33}$ Our modern concept of life as a property makes us unable to conceive Dionysian understanding of it. In my view we tend to see life as something that the body does or does not have. Being alive, then, is completely different from leading a daily life. But when being alive means constant struggle and strive towards a greater or even the ultimate principle, the difference between being alive and leading a life seems to fade. And this struggle for a human being means a constant effort to get out of the sensual world which is shattered into various perceptions of the unity of intellectual vision. Remembering that the true and highest form of life is the intellectual one we tend to see that those acts which lift the soul up towards the intellectual somehow make it more alive. This is not being more alive in the metaphorical sense, but in the ontological one, since it gives the soul shape and form which is in accord to its proper perfection.

In my opinion, in the case of Pseudo-Dionysius the unity of the concept of life is visible even more clearly than in the systems of his Neoplatonic predecessors. If we agree that there is only one principle of life and lower beings can grant life only in some sense (e.g. like granting understanding), in this world we cannot find any other life-giving principle. So Pseudo-Dionysius critique of the Proclian concept of secondary principles of life, which are Pagan gods, unifies the very notion of life even more. Although the Dionysian universe seems to some extent to be less alive it points more clearly at one life-making principle. Having in mind the Greek philosophical mentality, which in most cases wants to explain the universe referring to a single principle, we find Pseudo-Dionysius's concept of life as the perfect example of the Greek view of the Universe.

\footnotetext{
52 Cf. Pseudo-Dionysius, DN XI, 5, 952D, 3 - 953A, 8 (PTS 33, 220-221).

53 Hathaway, Hierarchy, 52.
} 


\section{Bibliography}

\section{Sources:}

Marius Victorinus, Adversus Arium [= Adv. Ar.]: Marius Victorinus, Traités théologiques sur la Trinité (ed. P. Hadot) (SCh 68; Paris: Cerf 1960) I.

Plato, Sophista: Platonis opera (ed. J. Burnet) (Oxford: Clarendon 1900, reprint 1967) I, 216-268.

Plotinus, Enneades: Plotini opera (eds. P. Henry - H.-R. Schwyzer) (Leiden: Brill 1964-1983) I-III, English trans. G. Boy-Stonses et al.: Plotinus, The Enneads (ed. L.P. Gerson) (Cambridge: Cambridge University Press 2018).

Proclus, Institutio theologica: Proclus, Elements of Theology (ed. E.R. Dodds) (Oxford: Clarendon 1963).

Proclus, Platonica theologia [= Plat. Theol.], Proclus, Théologie platonicienne (eds. H.D. Saffrey - L.G. Westerink) (Paris: Les Belles Lettres 1987) IV, English trans. T. Taylor: The Theology of Plato (Somerset: Prometheus Trust 1995).

Pseudo-Dionysius Areopagita, De Divnis Nominibus [= DN]; De Coelesti Hierarchia $[=\mathrm{CH}] ;$ De Ecclesiastica Hierarchia [=EH]; Epistulae [= Ep.]: Pseudo-Dionysius Areopagita, Corpus Dionysiacum. I. De divinis nominibus (ed. B.R. Suchla). II. De coelesti hierarchia. De ecclesiastica hierarchia. De mystica theologia. Epistulae (eds. G. Heil - A.M. Ritter) (Patristische Texte und Studien 33, 36; Berlin: De Gruyter 1990-1991), English trans. C. Luibheid: Pseudo-Dionysius, The Complete Works (The Classics of Western Spirituality; New York: Paulist Press 1987).

\section{Secondary literature:}

de Andia, Y., Henosis. L’union à Dieu chez Denys L’Aréopagite (Leiden - New York - Köln: Brill 1996).

Beere, J., Doing and Being. An Interpretation of Aristotle's Metaphysics Theta (Oxford: Oxford University Press 2009).

Bradshaw, D., Aristotle East and West. Metaphysics and the Division of Christendom (Cambridge: Cambridge University Press 2004).

Bussanich, J., "Plotinus's Metaphysics of the One," Cambridge Companion to Plotinus (ed. L. Gerson) (Cambridge: Cambridge University Press 1996) 38-65.

Chlup, R., Proclus. An Introduction (Cambridge: Cambridge University Press 2012).

Dillon, J. - Klitenic Wear, S., Dionysius the Areopagite and the Neoplatonist Tradition. Despoiling the Hellens (Aldershot: Ashgate 2007).

Hathaway, R.F., Hierarchy and Definition of Order in the Letters of Pseudo-Dionysius. A Study in the Form and Meaning of the Pseudo-Dionysian Writings (Hague: Nijhoff 1969).

Lloyd, A.C., Anatomy of Neoplatonism (Oxford: Oxford University Press 1990).

Louth, A., "The Reception of Dionysius in Byzantine World: Maximus to Palamas," Re-thinking Dionysius Areopagite (eds. S. Coakley - Ch. Stang) (Chichester: Wiley-Blackwell 2009) 55-70.

Schäfer, C., Philosophy of Dionysius the Areopagite. An Introduction to the Structure and the Content of the Treatise "On the Divine Names" (Leiden - Boston, MA: Brill 2006).

Stępień, T. - Kochańczyk-Bonińska, K., Unknown God, Known in His Activities. Incomprehensibility of God during the Trinitarian Controversy of the 4th Century (Berlin: Lang 2018). 